\title{
A thermodynamic evaluation of the addition of calcium and magnesium to an Ultisol: I - $\mathrm{Ca}(\mathrm{OH})_{2}$ addition 1
}

\author{
Gustavo A. Martínez: Lourdes Peña-Córdova,, \\ Luis A. Figueroa
}

\begin{abstract}
An experiment was conducted to determine the effects of two calcium sources on the chemistry of an Ultisol at various magnesium levels. A $2 \times 4$ $x 3$ complete factorial experimental design had two calcium sources $\left[\mathrm{Ca}(\mathrm{OH})_{2}, \mathrm{CaSO}_{4}\right]$; four calcium levels: control ( $0 \mathrm{Ca}$ added), $1 \times \mathrm{Ca}$ (1 meq $\mathrm{Ca} / \mathrm{meq} \mathrm{Al}$ ), 2x Ca (2 meq Ca/meq Al), 3x Ca (3meq Ca/meq Al), and three levels of magnesium: Control $(0, \mathrm{Mg}), 1 \times \mathrm{Mg}(10 \% \mathrm{CEC})$, and $2 \times \mathrm{Mg}(20 \%$ CEC). The addition of $\mathrm{Ca}(\mathrm{OH})_{2}$ increased the $\mathrm{pH}$ of the soil to approximately the following values: Control $-4.40 ; 1 \times \mathrm{Ca}-6.40 ; 2 \times \mathrm{Ca}-6.70 ; 3 \times \mathrm{Ca}-6.90$. This rise in $\mathrm{pH}$ more than doubled the sites available for exchangeable cations as $\mathrm{pH}$ dependent charges were created. A $20 \%$ decrease in exchangeable magnesium was observed without a consequent increase in the levels of magnesium in solution. This finding suggests that a fixation mechanism was precluding magnesium from becoming available, a condition which may create magnesium deficiency problems for the crops grown in these soils. The addition of magnesium to these samples increased their levels of soluble and exchangeable magnesium but had little effect on the overall fixation of magnesium. A decrease in $\mathrm{pH}$ in those samples previously limed with $\mathrm{Ca}(\mathrm{OH})_{2}$ caused a dramatic increase in the levels of calcium and magnesium in solution as a result of the release of cations from $\mathrm{pH}$ dependent charges in the case of calcium as well as the liberation of the magnesium possibly being held as a Mg-Al precipitate in the case of magnesium.
\end{abstract}

\section{RESUMEN}

Evaluación termodinámica de la adición de calcio y magnesio a un Ultisol

Se realizó un experinemto para determinar el efecto de dos fuentes de calcio en la química de un Ultisol a varios niveles de magnesio. El diseño experimental consistió de un factorial $2 \times 4 \times 3$ con dos fuentes de calcio: $\left[\mathrm{Ca}(\mathrm{OH})_{2}, \mathrm{CaSO}_{4}\right]$, cuatro niveles de calcio: control $(0 \mathrm{Ca}), 1 \times \mathrm{Ca}(1 \mathrm{meq} \mathrm{Ca} /$ meq Al), $2 \times \mathrm{Ca}(2 \mathrm{meq} \mathrm{Ca} / \mathrm{meq} \mathrm{Al})$ y tres niveles de magnesio: control $(0 \mathrm{Mg})$, $1 \times \mathrm{Mg}(10 \%$ del CEC total), $2 \times \mathrm{Mg}$ ( $20 \%$ del CEC total). La adición de $\mathrm{Ca}(\mathrm{OH}) 2$, causó un incremento en el $\mathrm{pH}$ del suelo en la siguiente propor-

'Manuscript submitted to Editorial Board 25 June 1992. Authors thank Eleanor Fontanet of the Statistics Section for her cooperation in the statistical analysis. This paper is lovingly dedicated to the memory of Gustavo Javier Martínez-Peña, late son of first two authors.

${ }^{2}$ Research Assistant, Department of Agronomy and Soils

- Former Laboratory Technician, Department of Agronomy and Soils.

${ }^{4}$ Assistant Technician, Department of Agronomy and Soils. 
ción: control, $4.40 ; 1 \times \mathrm{Ca}, 6.40 ; 2 \times \mathrm{Ca}, 6.70 ; 3 \times \mathrm{Ca}-6.90$. Este aumento en pH más que duplicó la capacidad de intercambio catiónico del suelo. Sin embargo, el magnesio intercambiable disminuyó en un $20 \%$ a consecuencia del incremento en $\mathrm{pH}$. Tampoco se observó ningún incremento en los niveles de magnesio en solución. Los resultados indican que un mecanismo de fijación evitó que el magnesio se hiciera disponible. La adición de magnesio al suelo causó un aumento en los niveles de magnesio intercambiable y en solución, pero no tuvo efecto alguno en el mecanismo de fijación de magnesio. Una reducción en el $\mathrm{pH}$ de las muestras previamente encaladas $\left[\mathrm{Ca}(\mathrm{OH})_{2}\right]$ causó un aumento considerable en los niveles de calcio y magnesio en solución. Esto se debe a la liberación de ambos cationes de las cargas dependientes de $\mathrm{pH}$, además de la liberación del magnesio previamente fijado.

\section{INTRODUCTION}

During the past two decades, soil scientists have shown a renewed interest in the factors that control the availability of magnesium to plants. The increase of fertilization programs as a result of a more intensive agriculture, and the lack of magnesium bearing materials in fertilizer fillings or in the lime source being applied to acid soils are factors that have increased the occurrence of magnesium deficient crops (2).

Highly weathered soils have frequently been the target of magnesium-related research. In recent years, such research has been focused on the effects of nutrient ratios such as $\mathrm{Mg}^{2+} / \mathrm{NH}_{4}+\mathrm{Mg}^{2+} / \mathrm{K}^{+}$, and liming on magnesium availability.

Liming acid soils to near neutrality has been shown to limit the availability of magnesium to plants (1, 5, 7, 9). In 1972, McLean and Carbonell (11) suggested some type of fixation mechanism to explain a magnesium depression in plants grown on a soil to which $\mathrm{Ca}(\mathrm{OH})_{2}$ had been applied. Later, Christenson, et al. (4), indicated that soil $\mathrm{pH}$ and not calcium level was responsible for the decrease in magnesium uptake in plants grown on limed highly weathered soils. Then in 1984, Pavan et al. (13) reported a decrease in the levels of exchangeable magnesium of an Oxisol limed with $\mathrm{CaCO}_{3}$, and Myers (12), stated that a range of $17 \%$ to $34 \%$ of the exchangeable magnesium could be "fixed" as a result of liming. They also indicated that such fixation was due to the coprecipitation of magnesium and aluminium polymers formed as a result of liming. Other mechanisms have been proposed by Chan, et al. (3), McBride (10), Grove, et al. (6), and Sumner (14).

Even when the fixation of magnesium has been clearly established, there are not much data available regarding its effects on soil solution equilibria and the possibility of reversing the process. The objectives of this study were 1) to determine the effects of two calcium sources $\left[\mathrm{Ca}(\mathrm{OH})_{2}, \mathrm{CaSO}_{4}\right]$ on the fixation of magnesium in a highly weathered 
soil; 2) to acquire more information on the effects of magnesium "fixation" on the chemistry of the soil solution and 3) to determine the effects of pH changes on the magnesium status of the soil after it has been amended with different calcium sources.

The results obtained for $\mathrm{Ca}(\mathrm{OH})_{2}$ are discussed here. The results for its counterpart, $\mathrm{CaSO}_{1}$, will be discussed in a forthcoming paper.

\section{MATERLALS AND METHODS}

The research began in the fall of 1990 . Our soil was from the surface layer of an Ultisol (clayey, mixed, isohyperthermic Typic Tropohumult) located at the Agricultural Experiment Station of Corozal, Puerto Rico. The following tabulation shows some relevant chemical properties of the soil.

$\begin{array}{lc}\text { Soil Property } & \text { Value } \\ \text { pH } & 4.44 \\ \mathrm{Al}, \mathrm{meq} / 100 \mathrm{~g} & 9.00 \\ \sum(\mathrm{Ca}+\mathrm{Mg}+\mathrm{K}) \text { meq } / 100 \mathrm{~g} & 4.50 \\ \mathrm{OM}(\%) & 3.00\end{array}$

Air dry soil was sieved to pass a $0.5 \mathrm{~mm}$ screen and 72 portions of $2.5 \mathrm{Kg}$ each (experimental units) were weighed and placed separately. Two calcium sources, $\mathrm{Ca}(\mathrm{OH})_{2}$ or $\mathrm{CaSO}_{4}$ (analytical reagents) were added to the soil to achieve the following calcium treatments:
1) Control
- 0 calcium
2) $1 \times$ calcium
$-1 \mathrm{meq} \mathrm{Ca} / \mathrm{meq} \mathrm{Al}$
3) $2 x$ calcium
- 2 meq $\mathrm{Ca} / \mathrm{meq} \mathrm{Al}$
4) $3 x$ calcium
-3 meq $\mathrm{Ca} / \mathrm{meq} \mathrm{Al}$

$\mathrm{MgSO}_{4}$ (analytical reagent) was then applied at the following rates:
1) control
- 0 magnesium
2) $1 \times$ magnesium
- $10 \%$ of the sum of cations
3) $2 x$ magnesium
$-20 \%$ of the sum of cations

The treatments were combined in a $2 \times 4 \times 3$ complete factorial experimental design (two $\mathrm{Ca}$ sources, four Ca levels, three $\mathrm{Mg}$ levels), (table 1). Each treatment was replicated 3 times and applied individually to the experimental units. The reagents were applied through a 0.1 $\mathrm{mm}$ sieve and mechanically mixed throughout the whole process to assure uniform distribution of the treatments. Distilled water was then added to each sample until a $20 \%$ moisture content was reached. Each experimental unit was then placed in 5-L pots and left to equilibrate at 
TABLE 1. Desicription of the treatments.

\begin{tabular}{|c|c|c|c|}
\hline Treatment & Ca source & $\mathrm{Ca}$ & $\mathrm{Mg}$ \\
\hline I 1. & $\mathrm{Ca}(\mathrm{OH})_{2}$ & Control & Control \\
\hline$I 2$ & $\mathrm{Ca}(\mathrm{OH})_{2}$ & $1 \times \mathrm{Ca}$ & Control \\
\hline I 3 & $\mathrm{Ca}(\mathrm{OH})_{2}$ & $2 \times \mathrm{Ca}$ & Control \\
\hline 14 & $\mathrm{Ca}(\mathrm{OH})_{2}$ & $3 \times \mathrm{Ca}$ & Control \\
\hline I 5 & $\mathrm{Ca}(\mathrm{OH})_{2}$ & Control & $1 \times M g$ \\
\hline 16 & $\mathrm{Ca}(\mathrm{OH})_{2}$ & $1 \times \mathrm{Ca}$ & $1 \times \mathrm{Mg}$ \\
\hline 17 & $\mathrm{Ca}(\mathrm{OH})_{i}$ & $2 \times \mathrm{Ca}$ & Ix $\mathrm{Mg}$ \\
\hline 18 & $\mathrm{Ca}(\mathrm{OH})_{2}$ & $3 \times \mathrm{Ca}$ & $1 \times \mathrm{Mg}$ \\
\hline 19 & $\mathrm{Ca}(\mathrm{OH})_{2}$ & Control & $2 \times \mathrm{Mg}$ \\
\hline I 10 & $\mathrm{Ca}(\mathrm{OH})_{2}$ & $1 \times \mathrm{Ca}$ & $2 \times \mathrm{Mg}_{\mathrm{g}}$ \\
\hline I 11 & $\mathrm{Ca}(\mathrm{OH})_{2}$ & $2 \times \mathrm{Ca}$ & $2 \times \mathrm{Mg}$ \\
\hline I 12 & $\mathrm{Ca}(\mathrm{OH})_{2}$ & $3 \times \mathrm{Ca}$ & $2 \times \mathrm{Mg}$ \\
\hline II 1 & $\mathrm{CaSO}_{4}$ & Control & Control \\
\hline II 2 & $\mathrm{CaSO}_{4}$ & $1 \times \mathrm{Ca}$ & Control \\
\hline II 3 & $\mathrm{CaSO}_{4}$ & $2 \times \mathrm{Ca}$ & Control \\
\hline II 4 & $\mathrm{CaSO}_{4}$ & $3 \times \mathrm{Ca}$ & Control \\
\hline II 5 & $\mathrm{CaSO}_{4}$ & Control & 1x $\mathrm{Mg}$ \\
\hline II 6 & $\mathrm{CaSO}_{4}$ & $1 \mathrm{x} \mathrm{Ca}$ & $1 \times M g$ \\
\hline II 7 & $\mathrm{CaSO}_{4}$ & $2 \times \mathrm{Ca}$ & $1 \times \mathrm{Mg}$ \\
\hline II 8 & $\mathrm{CaSO}_{4}$ & $3 \times \mathrm{Ca}$ & $1 \times \mathrm{Mg}$ \\
\hline I: 9 & $\mathrm{CaSO}_{4}$ & Control & $2 \times \mathrm{Mg}$ \\
\hline II 10 & $\mathrm{CaSO}_{4}$ & $1 \times \mathrm{Ca}$ & $2 \times \mathrm{Mg}$ \\
\hline II 11 & $\mathrm{CaSO}_{4}$ & $2 \times \mathrm{Ca}$ & $2 \times M g$ \\
\hline IX 12 & $\mathrm{CaSO}_{4}$ & $3 \times \mathrm{Ca}$ & $2 \times M g$ \\
\hline
\end{tabular}

room temperature. After 48 hours (12/18/91 - referred to hereafter as first date), samples from each pot were collected and analyzed for:

1) Exchangeable cations - $\mathrm{Ca}^{2+}, \mathrm{Mg}^{2+}, \mathrm{K}^{+}$, and $\mathrm{Al}^{3+}$

2) Water soluble cations - $\mathrm{Ca}^{2+}, \mathrm{Mg}^{2+}$, and $\mathrm{K}^{+}$

3) $\mathrm{pH}$

Exchangeable $\mathrm{Ca}^{2+}, \mathrm{Mg}^{2+}$, and $\mathrm{K}^{+}$were extracted with $1.0 \mathrm{~N} \mathrm{NH}_{4} \mathrm{OAC}$ (pH 7.0) and exchangeable $\mathrm{Al}^{3+}$ with $1.0 \mathrm{~N} \mathrm{KCl}$. All cations were measured in a Perkin-Elmer atomic absorption spectrophotometer. Flame emission was used for potassium, and atomic absorption for calcium, magnesium, and aluminum. Soil solution ions were measured by atomic absorption and $\mathrm{pH}$ was measured in a Fisher ion analyzer. All suspensions were obtained from a 2:1 water-soil ratio.

A month after the treatments had been applied (1/18/91 - from now on referred to as second date), soil samples from each pot were collected 
once more and submitted to the same analyses. At this stage, a dilute solution of $\mathrm{HCl}$ was added to the samples previously limed with $\mathrm{Ca}(\mathrm{OH}) 2$ to lower their $\mathrm{pH}$ to near natural levels $(4.40)$, and $\mathrm{NaOH}$ was added to the samples amended with $\mathrm{CaSO}_{4}$ to raise their $\mathrm{pH}$ to $>5.6$.

Two months later (3/18/91 - third date) samples were collected again and the same analyses were performed. The data were submitted to the statistical division of the Agricultural Experiment Station at Rio Piedxas, where they were analyzed according to a $2 \times 4 \times 3$ complete factorial experimental design.

\section{RESULTS AND DISCUSSION}

Calcium in solution-(Ca-s):

Table 2 shows the effects of calcium addition on the levels of Ca-s on different dates. In general, $\mathrm{Ca}$-s increased gradually as a result of the calcium additions (fig. 1). The levels of $\mathrm{Ca}$-s for the control remained virtually unchanged throughout the experiment (table 3 ). However, the acidification of the samples to $\mathrm{pH}$ values close to the natural $\mathrm{pH}$ of the soil (4.40) caused a dramatic increase in the concentration of Ca-s. This release of calcium came as a result of the disappearance of $\mathrm{pH}$ dependent sites caused by the addition of HCI to the samples. The highest calcium treatment ( $3 \mathrm{x} \mathrm{Ca}$ ) experienced the lowest increase in Ca-s. This was due to a failure in decreasing the $\mathrm{pH}$ of such samples close to their natural levels (table 4). Apparently, a significant amount of $\mathrm{pH}$ dependent charges were still present at $\mathrm{pH} 4.98$.

Table 5 shows the effects of magnesium addition on the level of calcium. On the first two dates $(12 / 90,1 / 91)$, an increase in the levels of Ca-s was observed as the result of the magnesium addition. This was probably due to the release of exchangeable calcium as magnesium competed for exchangeable sites. This behavior is expected to be more

TABLE 2.-Effects of Ca addilion on Ca-s $\mathrm{mg} / \mathrm{kg}$.

\begin{tabular}{cccc}
\hline Treatment & $12 / 90$ & $1 / 91$ & $3 / 91$ \\
\hline Control Ca & $44 \mathrm{a}$ & $24 \mathrm{a}$ & $32 \mathrm{a}$ \\
$1 \times \mathrm{Ca}$ & $144 \mathrm{~b}$ & $108 \mathrm{~b}$ & $812 \mathrm{~b}$ \\
$2 \times \mathrm{Ca}$ & $152 \mathrm{bc}$ & $168 \mathrm{c}$ & $1236 \mathrm{c}$ \\
$3 \times \mathrm{Ca}$ & $176 \mathrm{c}$ & $184 \mathrm{c}$ & $1032 \mathrm{~d}$ \\
& & & $\mathrm{~b}, \mathrm{c}, \mathrm{d}>\mathrm{a} 1 \%$ \\
& $\mathrm{~b}, \mathrm{c}>\mathrm{a} 1 \%$ & $\mathrm{~b}, \mathrm{c}>\mathrm{a} 1 \%$ & $\mathrm{c} 1 \% \mathrm{~b} 1 \%,>\mathrm{d} 5 \%$ \\
& $\mathrm{c}>\mathrm{b} 5 \%$ & $\mathrm{c}>\mathrm{b} 1 \%$ & $\mathrm{~d}>\mathrm{b} 5 \%$ \\
\hline
\end{tabular}




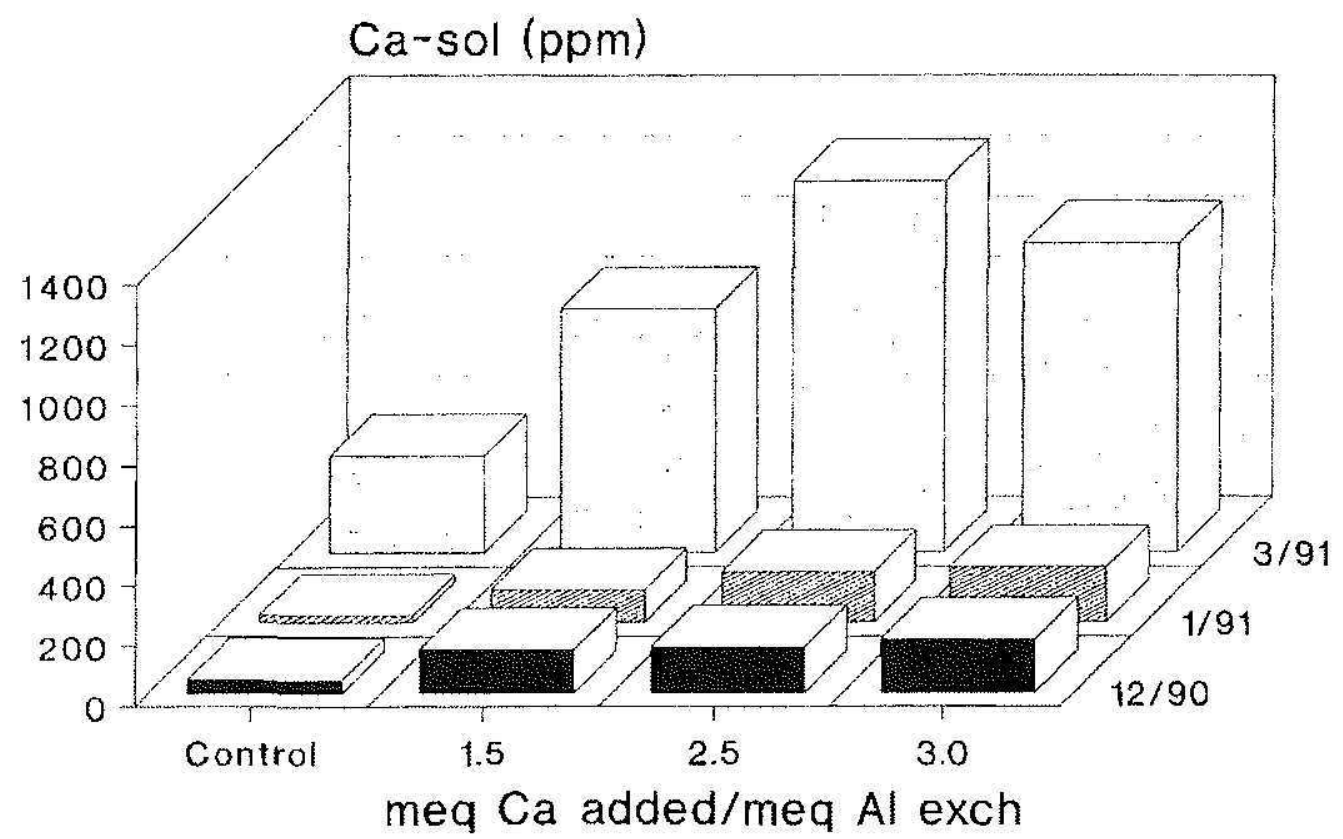

FIG. 1. Effects of liming on the levels of $\mathrm{Ca}-\mathrm{s}[\mathrm{Ca}(\mathrm{OH}) 2]$.

evident at the control ( $\mathrm{Ca}$ ), where little or no $\mathrm{pH}$ dependent sites capable of retaining cations are available, and it is expected to become less significant at the highest calcium treatments where enough charges have been created as a result of liming. Therefore, the increase in Ca-s may in fact be a reflection of what is happening in the control (calcium) treatment.

The effects of magnesium addition were no longer evident on the third date where higher amounts of calcium were being released from the $\mathrm{pH}$ dependent sites as a result of the drop in $\mathrm{pH}$.

Exchangeable calcium -(Ca-e):

As for Ca-s, there was a gradual increase in the levels of Ca-e as a result of the calcium treatments (table 6 ). The slightly higher values on

TABLE 3.-Between dates comparison of the levels of calcium in solution ( $\mathrm{mg} / \mathrm{kg}$ ).

\begin{tabular}{rcccc}
\hline Dates & Control & $1 \times \mathrm{Ca}$ & $2 \times \mathrm{Ca}$ & $3 \times \mathrm{Ca}$ \\
\hline $12 / 90$ & 44 & $144 \mathrm{a}$ & $152 \mathrm{a}$ & $176 \mathrm{a}$ \\
$1 / 91$ & 24 & $188 \mathrm{a}$ & $168 \mathrm{a}$ & $184 \mathrm{a}$ \\
$3 / 9 \mathrm{~d}$ & 32 & $812 \mathrm{~b}$ & $1236 \mathrm{~b}$ & $1032 \mathrm{~b}$ \\
increase & & & & \\
(3rd vs. 2nd) & $8 \mathrm{ppm}$ & $704 \mathrm{ppm}$ & $1068 \mathrm{ppm}$ & $848 \mathrm{ppm}$ \\
(3rd vs. 2nd) & $33 \%$ & $652 \%$ & $636 \%$ & $461 \%$ \\
& & b>a 1\% & b>a 1\% & b>a 1\% \\
\hline
\end{tabular}


TABLE 4 $\rightarrow$ pH values for the Ca treatments.

\begin{tabular}{ccccc}
\hline Dates & Control & $1 \times \mathrm{Ca}$ & $2 \times \mathrm{Ca}$ & $3 \times \mathrm{Ca}$ \\
\hline $12 / 90$ & 4.40 & 6.49 & 7.13 & 7.88 \\
$1 / 91$ & 4.39 & 6.44 & 6.71 & 6.87 \\
$3 / 91$ & 4.28 & 4.07 & 4.25 & 4.98 \\
\hline
\end{tabular}

the first date as compared to those on the second were probably due to an incomplete dissolution of the $\mathrm{Ca}(\mathrm{OH})_{2}$ within the 48 hours of the first measurements. This was more evident at the highest calcium treatments. On the second date, enough time ( 1 month) for the treatments to react had passed and a stage of minimum change was probably reached.

On the third date, all treatments but the control experienced sharp decreases in the amount of Ca-e (table 6). This came as a result of a decrease in $\mathrm{pH}$ dependent sites because of acidification of the samples with $\mathrm{HCl}$. Almost half of the sites on the second date were accountable to variable charges. This finding represents an option that if properly managed should result in benefits to the crops grown in this type of soil. Highly weathered soils have long been recognized for their low natural fertility and low levels of basic cations. An increase in exchange sites certainly opens the door for the enrichment of their fertility level. However, it is important to realize the detrimental effects that overliming can cause in most crops. Besides a possible decrease in the availability of magnesium to plants, micronutrient deficiencies, as well as deterioration of the physical properties of the soil, have been reported as a consequence of overliming (8). Phosphorus deficiencies and the disruption of the microbial ecosystem are also well documented effects of such practice. Therefore, it should be kept in mind that the goal of liming is to decrease aluminium and manganese in the soil to nontoxic levels. If by doing so additional sites for exchangeable cations are created, we must take advantage of that phenomenon and thus create the best nutritional environment for the crops (11). The saturation of the exchange

TABLE 5.-Effects of $\mathrm{Mg}$ addition on the levels of Ca-s ( $\mathrm{mg} / \mathrm{kg}$ ).

\begin{tabular}{cccc}
\hline Treatment & $12 / 18 / 90$ & $1 / 18 / 91$ & $3 / 18 / 91$ \\
\hline Control $(\mathrm{Mg})$ & $92 \mathrm{a}$ & $84 \mathrm{a}$ & $844 \mathrm{a}$ \\
$1 \mathrm{x} \mathrm{Mg}$ & $132 \mathrm{~b}$ & $120 \mathrm{~b}$ & $736 \mathrm{a}$ \\
$2 \times \mathrm{Mg}$ & $164 \mathrm{~b}$ & $156 \mathrm{c}$ & $752 \mathrm{a}$ \\
& & $\mathrm{b}, \mathrm{c}>\mathrm{a} 5 \%$ & \\
\hline
\end{tabular}


TABLE 6.-Effect of Ca additions on the levels of Ca-e (meq / $100 \mathrm{~g}$ ).

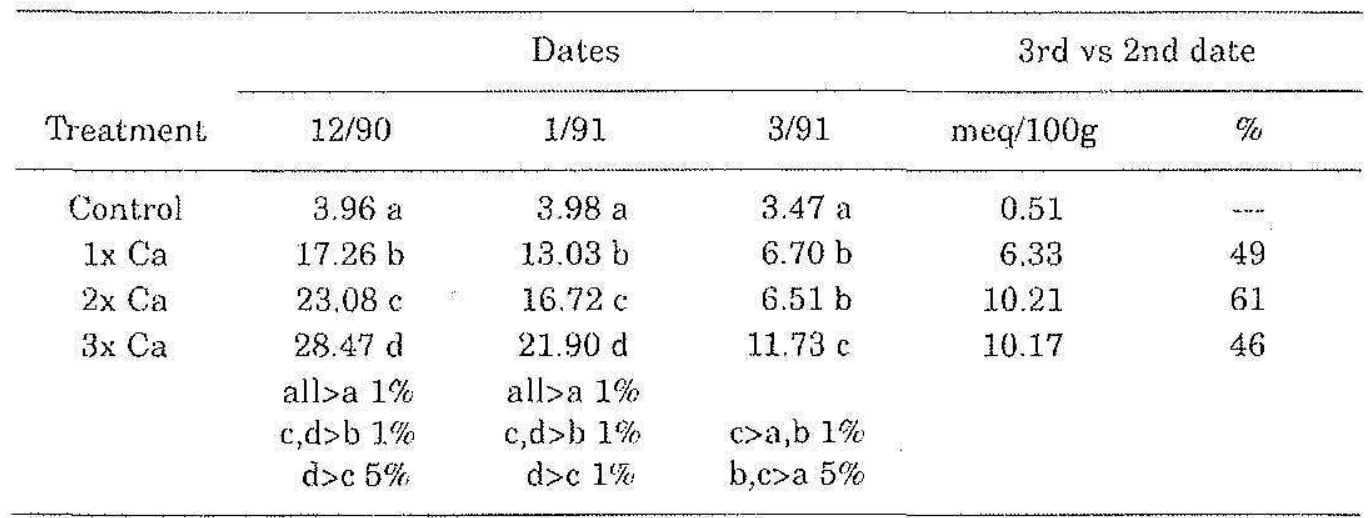

complex by a single cation must be avoided because of the difficulties that this practice creates in terms of nutrient balance and availability.

Magnesium in solution -( $M g-s)$ :

Table 7 shows the effects of calcium addition on $\mathrm{Mg}$-s. There is a tendency for the Mg-s to decrease as calcium addition increases (1st and 2nd dates). This indicates that some kind of mechanism is tying up the magnesium being released from the exchange sites as calcium is being added. In other words, one would expect the levels of Mg-s to increase as a consequence of liming unless precipitation, complexation, chelation, plant uptake, or leaching consumes the magnesium being generated. Ruling out plant uptake and lixiviation, which do not apply to this case, and recognizing that either soluble organic or inorganic complexation would have been refiected in the analyses, we are left with some kind of mechanism (possibly precipitation) that decreases

TABde 7.-Effects of calcium addition on the levels of $M g-s(\mathrm{mg} / \mathrm{kg})$.

\begin{tabular}{|c|c|c|c|c|c|}
\hline \multirow[b]{2}{*}{ Tmt. } & \multicolumn{3}{|c|}{ Dates } & \multicolumn{2}{|c|}{$\begin{array}{c}\text { Increase } \\
\text { (3rd vs 2nd date) }\end{array}$} \\
\hline & $12 / 90$ & $1 / 91$ & $3 / 91$ & ppm & $\%$ \\
\hline Control & $12.25 \mathrm{a}$ & $7.35 \mathrm{a}$ & $7.4 \mathrm{a}$ & 0.0000 & -- \\
\hline $1 \times \mathrm{Ca}$ & $7.35 \mathrm{~b}$ & $7.35 \mathrm{a}$ & $36.7 \mathrm{~b}$ & 29.4 & 400 \\
\hline $2 \mathrm{x}^{\mathrm{Ca}}$ & $2.45 \mathrm{c}$ & $4.90 \mathrm{a}$ & $36.7 \mathrm{~b}$ & 32.0 & 650 \\
\hline \multirow[t]{3}{*}{$3 \times \mathrm{Ca}$} & $2.45 \mathrm{c}$ & $4.90 \mathrm{a}$ & $32.0 \mathrm{~b}$ & 27.0 & 550 \\
\hline & $\begin{array}{l}a>c 1 \% \\
a>b 5 \%\end{array}$ & & & & \\
\hline & $\mathrm{b}>\mathrm{c} 1 \%$ & & $b>a 1 \%$ & & \\
\hline
\end{tabular}




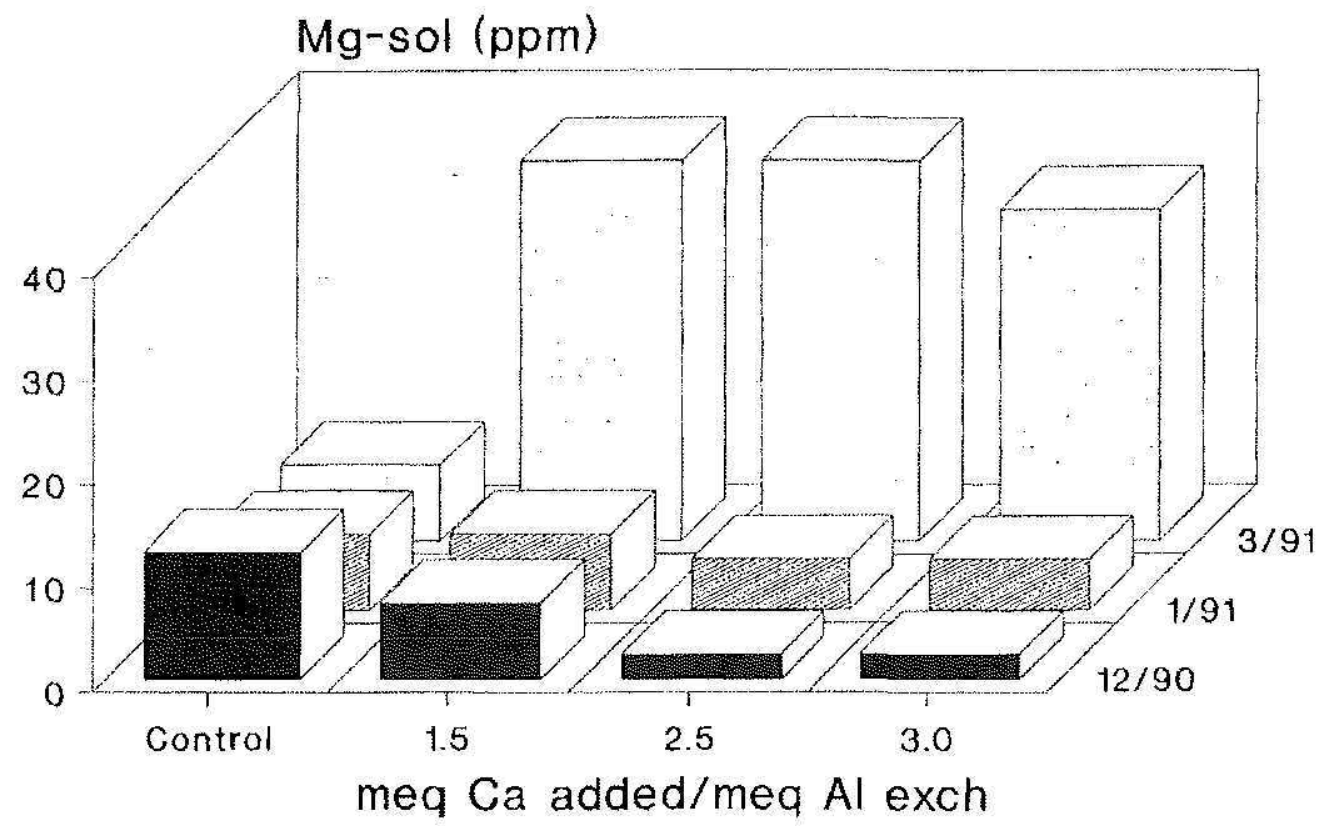

Fra. 2. Effects of liming on the levels of $\mathrm{Mg}-\mathrm{s}[\mathrm{Ca}(\mathrm{OH}) 2]$.

the availability of magnesium. The most generally accepted mechanism up to now is the coprecipitation of aluminium and magnesium to form an amorphous gel $(10,5)$.

Table 7 also shows the comparison among dates for the different treatments. A significant increase in $\mathrm{Mg}$-s resulted from the $\mathrm{pH}$ drop experienced on the third date. This increase (more than four times the previous) should prove to be beneficial to plants growing in this type of soil, where magnesium deficiency is very common. It is important to recognize, however, that the $\mathrm{pH}$ of these soils must not be allowed to drop below those levels at which aluminium toxicity represents a problem to crop growth. Furthermore, the drop in $\mathrm{pH}$ observed here is a magnification of what is likely to occur in soils under natural conditions. This kind of $\mathrm{pH}$ drop will probably take several years in soils, depending on many factors, such as type and amount of fertilizer added, precipitation, history of the soil (whether it has been limed for years or not) and the mineralogy of the soil. Therefore, under natural conditions it would be more likely to expect a gradual release of magnesium as the $\mathrm{pH}$ returns to the natural levels, acting like some kind of slow release magnesium fertilizer.

Exchangeable magnesium -(Mg-e):

Table 8 shows the effects of calcium addition on the levels of Mg-e. It took more than 48 hours for the effects of the calcium treatments to 
be completely achieved. This finding has been discussed previously in this paper. The decrease in $\mathrm{Mg}$-e observed for the calcium treatments (relative to the control) on the 2 nd date (table 8) ranks within the 18 to 34\% magnesium fixation reported by Myer (12), but falls short of the $49 \%$ reduction observed by Martínez (12) for a similar soil. There is no doubt, however, of the adverse effects that this process can have on magnesium availability since a $20 \%$ decrease represents a dramatic figure when one considers the low natural levels usually encountered in these soils.

Table 9 shows the overall effects (average of dates) of the interactions between the calcium and magnesium treatments. The addition of magnesium increased the levels of exchangeable magnesium present at each level of calcium. However, there is still an overall decrease in magnesium as a result of the calcium addition. The low overall effect of the $3 \times \mathrm{Ca}$ treatment is probably a reflection of the third date, where there were still some exchangeable cations present of $\mathrm{pH}$ dependent sites.

\section{CONCLUSIONS}

An increase of approximately $100 \%$ in the sites available for exchangeable cations came as a result of liming. This increase, therefore, if properly managed can be used to raise the fertility levels of these soils to adequate levels. However, we have seen that if overlimed [especially with a pure calcium amendment such as $\mathrm{Ca}(\mathrm{OH})_{2}$ ] the levels of exchangeable and soluble magnesium in the soil are decreased to levels that can be detrimental to the proper growth of most crops (other possible consequences of overliming are mentioned).

The addition of magnesium as part of the liming process increased both magnesium in solution and in the exchangeable phase although an overall "fixation" occurred as a result of the $\mathrm{pH}$ increase. The magnesium that becomes fixed as part of the liming process will eventually

TABLE 8.-Effects of Ca addition on Mg-e (meq / $100 \mathrm{~g}$ ).

\begin{tabular}{|c|c|c|c|c|c|}
\hline \multirow[b]{2}{*}{ Tmit. } & \multirow[b]{2}{*}{$12 / 90$} & \multirow[b]{2}{*}{$1 / 91$} & \multirow[b]{2}{*}{$3 / 91$} & \multicolumn{2}{|c|}{ Fixation (2nd date) } \\
\hline & & & & meq $/ 100 \mathrm{~g}$ & $\%$ \\
\hline Control & $1.21 \mathrm{a}$ & $1.18 \mathrm{a}$ & $0.93 a$ & -- & -- \\
\hline $1 \times \mathrm{Ca}$ & $1.17 \mathrm{a}$ & $0.96 \mathrm{~b}$ & $0.58 \mathrm{~b}$ & 0.22 & 19 \\
\hline $2 \times \mathrm{Ca}$ & $1.34 \mathrm{a}$ & $0.94 \mathrm{~b}$ & $0.56 \mathrm{~b}$ & 0.24 & 20 \\
\hline $3 \times \mathrm{Ca}$ & $1.40 \mathrm{a}$ & $\begin{array}{c}0.90 b \\
a>b \quad 1 \%\end{array}$ & $\begin{array}{c}0.73 b \\
a>b 1 \%\end{array}$ & 0.28 & 24 \\
\hline
\end{tabular}


TABLE 9.-Effects of Mg addition on the levels of $\mathrm{Mg}$ e at each level of $\mathrm{Ca}(\mathrm{meq} / \mathrm{l00 \textrm {g }}$ ).

\begin{tabular}{cccc}
\hline Theatments & Control $(\mathrm{Mg})$ & $1 \times \mathrm{Mg}$ & $2 \times \mathrm{Mg}$ \\
\hline Control Ca & $0.64 \mathrm{a}$ & $1.07 \mathrm{a}$ & $1.62 \mathrm{a}$ \\
$1 \times \mathrm{Ca}$ & $0.41 \mathrm{~b}$ & $0.96 \mathrm{ab}$ & $1.32 \mathrm{bc}$ \\
$2 \times \mathrm{Ca}$ & $0.46 \mathrm{~b}$ & $0.82 \mathrm{~b}$ & $1.54 \mathrm{ab}$ \\
$3 \mathrm{x} \mathrm{Ca}$ & $0.65 \mathrm{a}$ & $1.01 \mathrm{a}$ & $1.40 \mathrm{bc}$ \\
& & & $\mathrm{a}>\mathrm{c} 1 \%$ \\
& $\mathrm{a}>\mathrm{b} 5 \%$ & $\mathrm{a}>\mathrm{bc} 5 \%$ \\
& & $\mathrm{ab} 5 \% \mathrm{c} 5 \%$ \\
\hline
\end{tabular}

become available to plants as the $\mathrm{pH}$ of the soil returns to its natural levels. This process may take a few years depending on the amount and type of fertilizer added, the soil's mineralogy and other factors.

By experience, agronomists know that most farmers in Puerto Rico will frequently apply lime in excess to the amounts generally required for the proper growth of crops. Although we must educate them as to the adverse effects that such a practice may create, it may be a good idea to recommend the inclusion of magnesium as part of the liming process. In this way, we are assuring some supply of magnesium to the crops; initially, when we plant them and, in the long run, when some of the magnesium, which becomes fixed in part of the liming process, is released as the soil returns to its natural $\mathrm{pH}$ level.

\section{REFERENCES}

1. Adams, F. and J.B. Henderson, 1962. Magnesium availability as affected by deficient and adequate levels of potassium and lime. Soil Sci. Soc. Proc. 65-8.

2. Camp, A. F., 1949. Magnesium in citrus fertilization in Florida. Fla. Agric. Exp. Sta. Bull. 335.

3. Chan, K.Y., B.G. Davey and H.G. Geering, 1979. Adsorption of magnesium and calcium by a soil with variable charge. Soil Sci. Soc. Am. J. 43: 301-4.

4. Christenson, D.R., R.P. White and E.C. Doll, 1973. Yields and magnesium uptake by plants as affected by soil $\mathrm{pH}$ and calcium levels. Agron. J. 65:205-6.

5. Grove, J.H., and M.E. Sumner, 1985. Lime induced magnesium stress in corn: Impact of magnesium and phosphorus availability. Soil Sci. Soc. Am. J. 49: 1192-96.

6. - - . - - and J.K. Syers, 1981. Effect of lime on exchangeable magnesium in variable surface soils. Soil Sci. Soc. Am. J. 45: 497-500.

7. Juo, A.S.R., and F.O. Uzu, 1977. Liming and nutrient interactions in two ultisols from southern Nigeria. Plant and Soil. 47: 419-30.

8. Kamprath, E.J., 1971. Potential detrimental effects of liming highly weathered soils to neutrality. Soil and Crop Sci. Soc. of Florida. 31: 200-3.

9. Martínez G.A., 1991. The effects of liming on the exchangeable magnesium levels of t.wo highly weathered soils of Puerto Rico. J. Agric. Univ. P.R. 75 (1): 101-4.

10. McBride, M.B., 1978. Retention of $\mathrm{Cu}^{2+}, \mathrm{Ca}^{2+}, \mathrm{Mg}^{2+}$, and $\mathrm{Mn}^{2+}$ by amorphous alumina. Soil Sci. Soc. Am. J. 42: 27-31. 
11. McLean, E.O and M.D. Carbonell, 1972. Calcium, magnesium, and potassium saturation ratios in two soils and their effects upon yields and nutrient contents of German millet and alfalfa. Soil Sci. Soc. Am. Proc. 36: 927-30.

12. Myers, J.A., E.O. McLean and J.M. Bigham, 1988. Reductions in exchangeable magnesium with liming of acid Ohio soils. Soil Sci. Soc. Am. J. 52: 131-36.

13. Pavan, M.A., F.T. Bingham and P.F. Pratt, 1984. Redistribution of exchangeable calcium, magnesium, and aluminum following lime or gypsum applications to a brazilian oxisol. Soil Sci. Soc. Am. J. 48: 33-8.

14. Sumner, M.E., P.M.W. Farina and V.J. Hurst, 1978. Magnesium Fixation-a possible cause of negative yield responses to lime applications. Commun. Soil Sci. Plant Anal. 9: 995-1007. 